\title{
Histological Changes of Stomach and Intestine Induced by Energy Drink (Tiger) in Adult Male Rats
}

\author{
Maha Alsammak (D), Ahmed Hisham Qassim*(D), Omer R. Hamdi \\ Department of Anatomy, Histology and Embryology, College of Medicine, University of Mosul, Mosul, Nineveh, Iraq
}

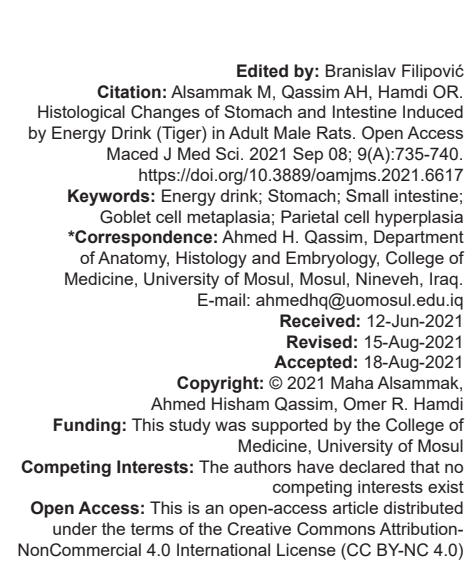

Introduction

The relation between the health benefits and risks of energy drinks is still controversial. Energy drinks comprise a combination of energy boosters and stimulants which have an impact on increasing physical attitude, body built, concentration, and mood [1]. In general, the ingredients contained within these drinks include caffeine, guarana, taurine, sugar, Vitamin B6, and sodium [2]. Moreover, other ingredients can be added such as glucuronolactone, ginkgo biloba, ginseng, and others [3]. One of these energy drinks is Tiger "Al Arabia co. LTD, Jordan" which is rich in B Vitamins, taurine, and caffeine $(32 \mathrm{mg} / 10 \mathrm{ml})$ in addition to other ingredients including water, sugar, acidity regulators (citric acid and sodium citrate), carbon dioxide, flavoring, inositol, colors: E 150d and riboflavin [4]. Tiger is one of the most popular drinks in our locality that is administered to boost energy. It is marketed for young people to increase their physical and cognitive performance [5]. Despite their beneficial effects, these drinks will be associated with many health disorders due to their effect on several organs such as the liver, kidney, heart, and brain [6], [7].

Few literatures are available about the effect of energy drinks on the stomach and intestine. Hence, the current study try to disclose this effect and aims to assess the histopathological changes that occur in the stomach and small intestine in adult male rats on account of energy drinks.

\section{Materials and Methods}

This study took place in the College of Medicine, University of Mosul between March 2020 and January 2021.

\section{Chemicals}

The energy drink used in this study was the Tiger "WILD TIGER ENERGY DRINK, TOTAL ACTIVATION, $8.3 \mathrm{FL} \mathrm{OZ} \mathrm{(250} \mathrm{ml)".} \mathrm{It} \mathrm{was} \mathrm{bottled} \mathrm{by} \mathrm{AI}$ Arabia co. LTD in Jordan, and it was purchased from the local markets in Mosul, Iraq. Tiger contains B Vitamins, caffeine $(32 \mathrm{mg} / 10 \mathrm{ml})$, as well as, taurine besides other ingredients such as water, carbohydrate, carbon dioxide, acidity regulators like citric acid and sodium citrate, inositol, flavoring, colors, and riboflavin [4]. 


\section{Animals}

Thirty male adult albino Wistar rats weighing $250 \pm 10$ gram and aging 5-6 months had been obtained from animals house, College of Veterinary Medicine, University of Mosul. The animals were kept in experimental room under suitable temperature.

\section{Experimental design}

Rats have been divided into three groups (10 animals for each).

1. Group (A): is a control group given only standard diet and distilled water

2. Group (B): given the energy drink Tiger in a dose of $1 \mathrm{ml} / 100 \mathrm{mg} / \mathrm{rat} /$ day. This volume corresponds to three cans of tiger consumed by adult human of $70 \mathrm{~kg}$ body weight

3. Group (C): given the energy drink Tiger in a dose of $2 \mathrm{ml} / 100 \mathrm{mg} / \mathrm{rat} / \mathrm{day}$. This volume corresponds to six cans of tiger consumed by adult human of $70 \mathrm{~kg}$ body weight. The energy drink tiger was given to group (B) and (C) orally using gastric tube daily for 30 days. After completing the period, the animals were sacrificed and dissected, and then processed for further histological examination.

\section{Histological assessment}

After excising the stomach and small intestine, the specimens were fixed in $10 \%$ neutral buffered formalin for $24 \mathrm{~h}$. Tissue processing was done and then the histological sections were stained with hematoxylin and eosin ( $\mathrm{H}$ and $\mathrm{E})$ and examined via light microscope.

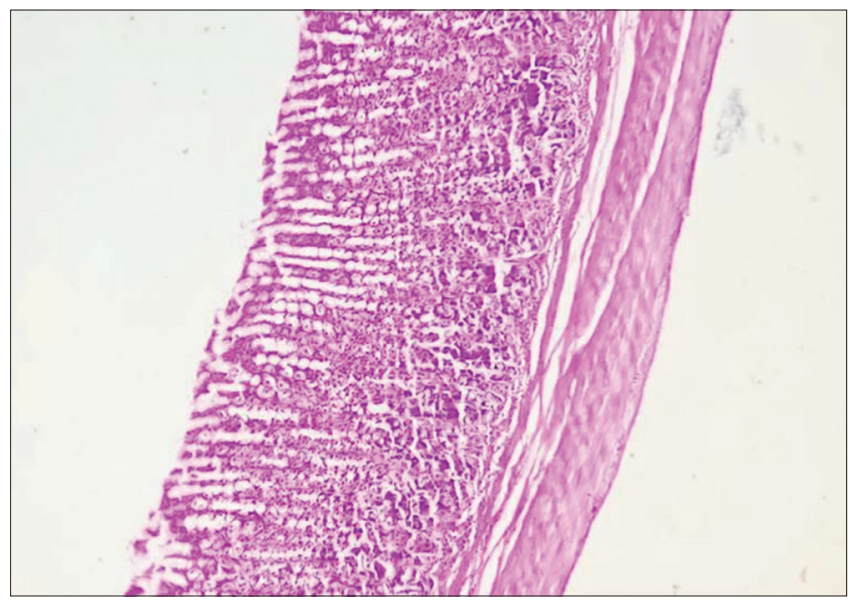

Figure 1: Microscopical picture of stomach tissue of control group (Group A) showing normal histology revealing mucosa, muscularis mucosae, submucosa (hematoxylin and eosin $\times 100$ )

\section{Ethical approval}

The research was approved by the Medical Research Ethics Committee, College of Medicine,

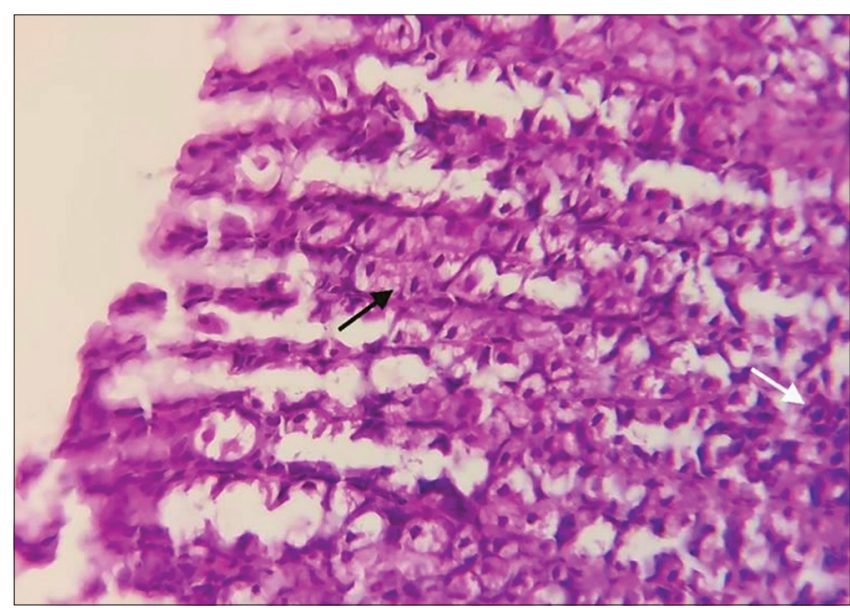

Figure 2: Microscopical picture of stomach tissue of control group (Group A) showing gastric glands of stomach, parietal cells (black arrow) and chief cells (white arrow) (hematoxylin and eosin $\times 400$ )

University of Mosul, Ref. no.: UOM/COM/MREC/2020(5) in $19 / 1 / 2020$.

\section{Results}

\section{Stomach}

Examination of gastric sections obtained from group A (control group) revealed normal histological structure of the stomach (Figures 1 and 2). Group B (which were given Tiger in a dose of $1 \mathrm{ml} / 100 \mathrm{mg} / \mathrm{day}$, low dose) showed obvious dilatation and congestion of blood vessels in the gastric submucosa (Figure 3 ) in addition to parietal cell hyperplasia which was seen throughout the whole gastric mucosa (Figure 4). Group C (which were given Tiger in a dose of $2 \mathrm{ml} / 100 \mathrm{mg} /$ day, high dose) has revealed marked dilatation and congestion of gastric blood vessels with infiltration of mononuclear cells (Figure 5). High power examination demonstrated very distinctive mononuclear cells infiltrate (Figure 6)

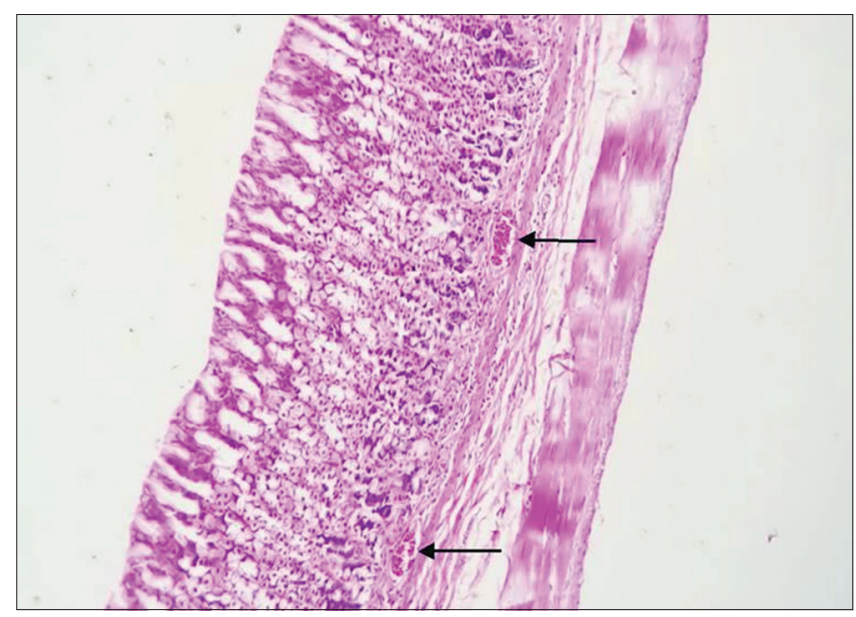

Figure 3: Microscopical picture of stomach tissue of Group B showing obvious dilatation and congestion of blood vessels of gastric submucosa (black arrows) (hematoxylin and eosin $\times 100$ ) 


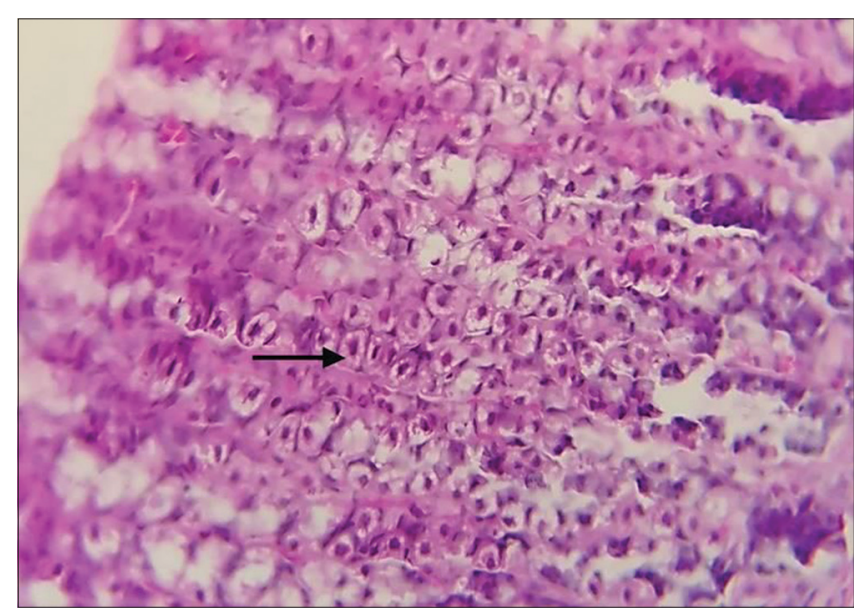

Figure 4: Microscopical picture of stomach tissue of group B showing parietal cell hyperplasia throughout the whole gastric mucosa (black arrow) (hematoxylin and eosin $\times 400$ )

in addition to goblet cell metaplasia and degeneration of surface epithelium (Figure 7). In all groups, the muscular layer and serosa were normal (Table 1).

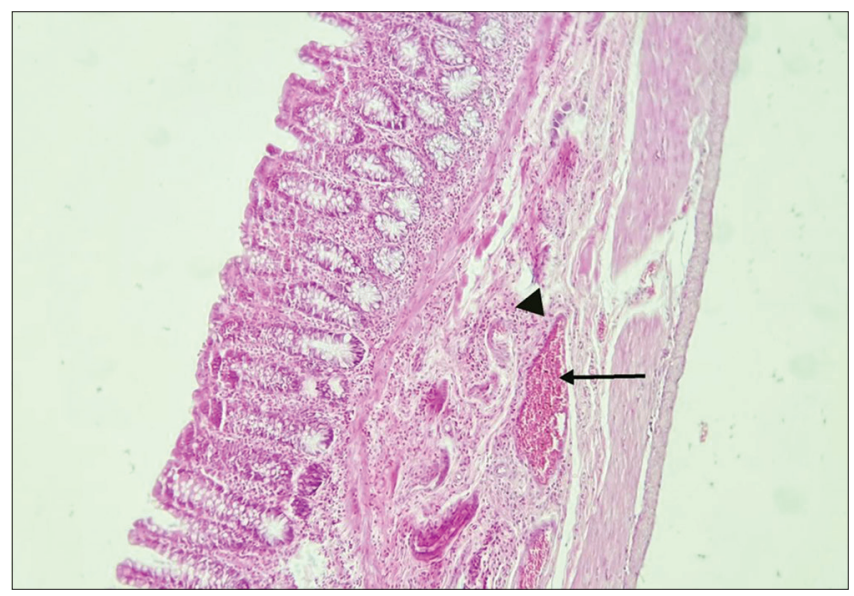

Figure 5: Microscopical picture of stomach tissue of group C showing marked dilatation and congestion of gastric blood vessels (black arrow) with infiltration of mononuclear cells (arrow head) (hematoxylin and eosin $\times 100$ )

\section{Small intestine}

Control group (Group A) sections stained with Hand E stain revealed normal histology (Figures 8 and 9 ).

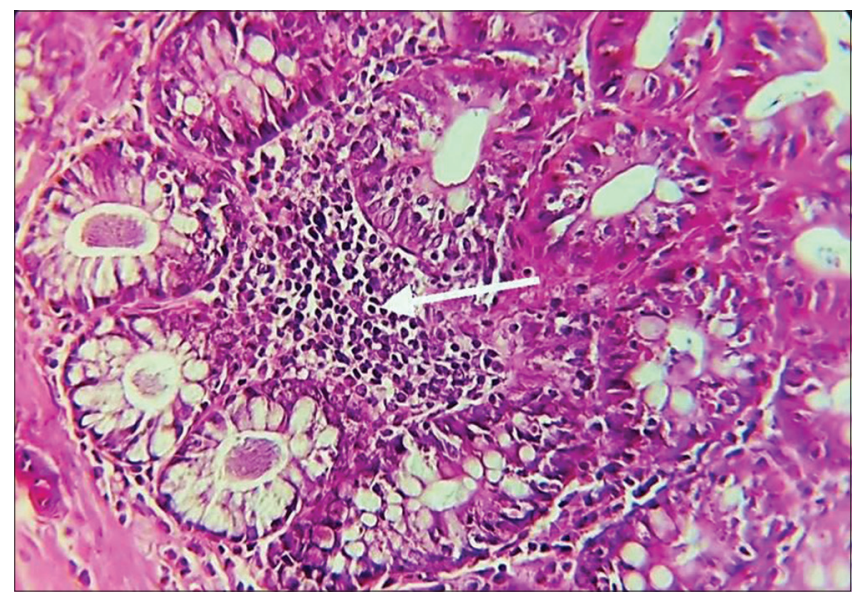

Figure 6: Microscopical picture of stomach tissue of Group C showing very distinctive mononuclear cells infiltrate (white arrow) (hematoxylin and eosin $\times 400$ )
Group B (given low dose of Tiger) had demonstrated congestion of intestinal blood vessels accompanied with a complete layer of hyalinization in the submucosa, along with partial loss of intestinal villi which was noticed too (Figure 10).

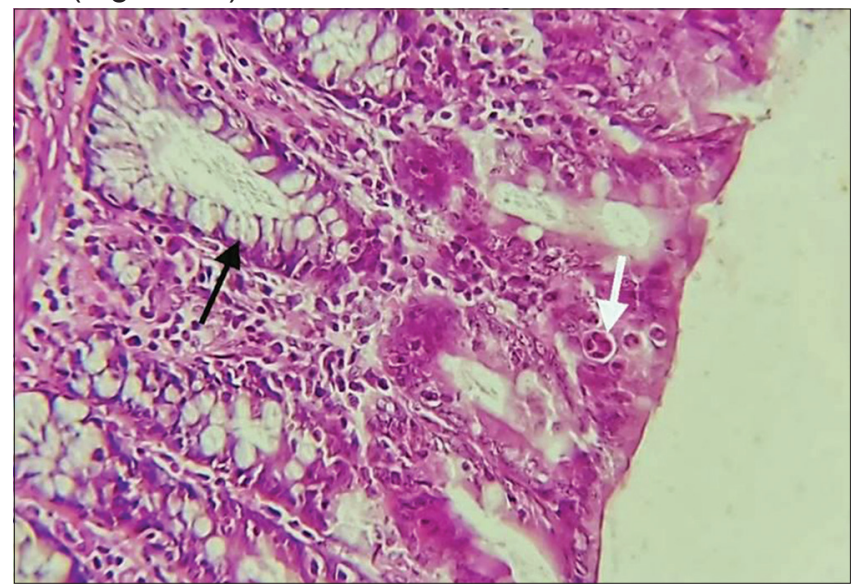

Figure 7: Microscopical picture of stomach tissue of Group C showing goblet cell metaplasia (black arrow) and degeneration of surface epithelium (white arrow) (hematoxylin and eosin $\times 400$ )

Furthermore, the sections showed goblet cell hyperplasia with a mild degree of inflammatory mononuclear cells infiltration (Figure 11).

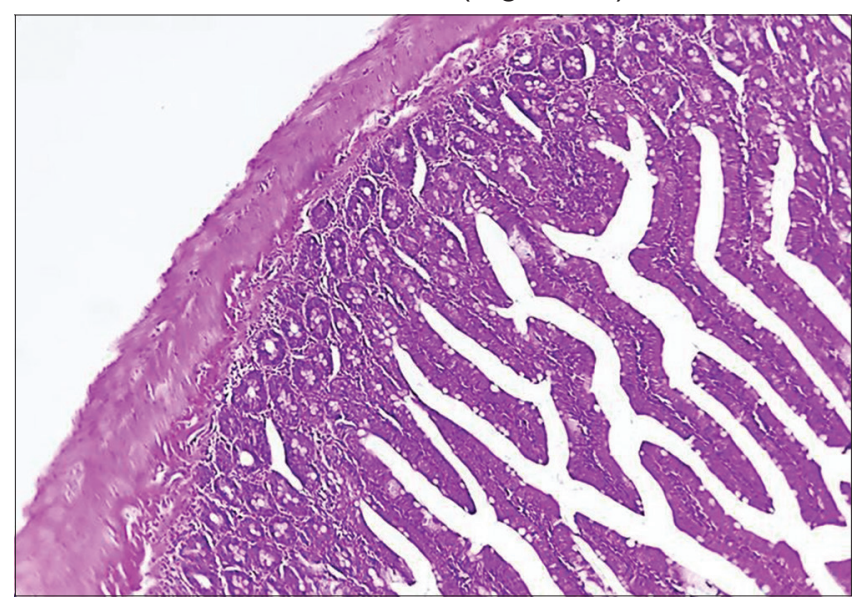

Figure 8: Microscopical picture of intestine tissue of control group (Group A) showing normal histology revealing mucosa, muscularis mucosae, submucosa (hematoxylin and eosin $\times 100$ )

Group C (given high dose of Tiger) showed a complete layer of hyalinization associated with congestion of intestinal blood vessels.

Also, destruction and complete loss of intestinal villi was seen in this group (Figure 12). Other findings observed in this group were degenerative changes of epithelial cells as well as marked goblet cell hyperplasia (Figure 13). The serosa and muscular layer were normal in all different groups (Table 1).

\section{Discussion}

A controversy still presents between the advantages and the possible health risks of energy 
Table 1: Histological changes of the stomach and intestine in the different groups

\begin{tabular}{|c|c|c|c|c|}
\hline \multicolumn{5}{|l|}{ Stomach } \\
\hline Groups & Mucosa & Submucosa & Muscular layer & Serosa \\
\hline Group A & Normal & Normal & Normal & Normal \\
\hline Group B & Parietal cell hyperplasia & Dilatation and congestion of blood vessels & Normal & Normal \\
\hline \multirow[t]{3}{*}{ Group C } & Goblet cell metaplasia & Marked dilatation and congestion of blood vessels with infiltration of & Normal & Normal \\
\hline & Degeneration of surface epithelium & mononuclear cells & & \\
\hline & Distinctive mononuclear cells infiltrate & & & \\
\hline \multicolumn{5}{|c|}{ Small intestine } \\
\hline Groups & Mucosa & Submucosa & Muscular layer & Serosa \\
\hline Group A & Normal & Normal & Normal & Normal \\
\hline \multirow[t]{2}{*}{ Group B } & Partial loss of intestinal villi Goblet cell hyperplasia & Congestion of blood vessels Complete layer of hyalinization & Normal & Normal \\
\hline & Mild degree of inflammatory mononuclear cells infiltration & & & \\
\hline Group C & $\begin{array}{l}\text { Complete loss of intestinal villi Degenerative changes of epithelial cells } \\
\text { Marked goblet cell hyperplasia }\end{array}$ & Congestion of blood vessels Complete layer of hyalinization & Normal & Normal \\
\hline
\end{tabular}

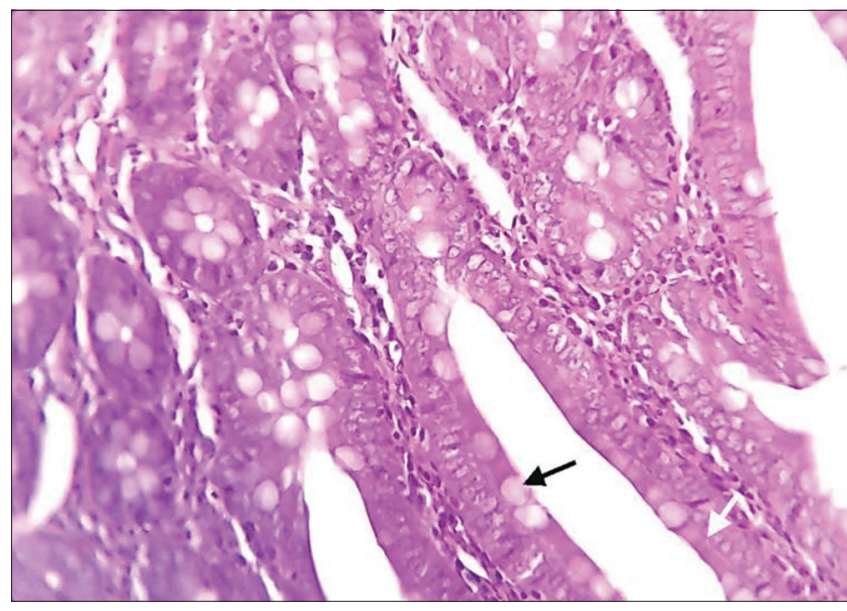

Figure 9: Microscopical picture of intestine tissue of control group (Group A) showing normal histology revealing intestinal villi with the lumen. Enterocytes (white arrow) and goblet cells (black arrow) are also evident (hematoxylin and eosin $\times 400$ )

drinks since their revolution [8]. Energy drinks have gained popularity in the market over the past several years. Adverse effects of energy drinks are increasingly common, which were found to be dose-dependent [9].

The current study revealed normal histological pattern in the stomach section in control group. Regarding the second group which was given a low dose of energy drink (Tiger), it was found that there are dilatation and congestion of blood vessels of gastric mucosa which may be attributed to increase in collagen formation and re-epithelization which goes with the result of Tek et al. [10]. associated with parietal cell hyperplasia that may be attributed to the main content of the energy drink (caffeine) which was found by other researchers to be the main stimulating factor for gastrin release and gastric acid secretion and promoting the gastro-esophageal reflux [11], or due to high content of carbohydrate contained within the energy drink which may stimulate insulin and glucose release which in turn will cause hyperplasia of the gastric epithelium [8].

Uwaifo found that consuming 2-3 cans of energy drink for 4 months may be related to gastritis, hepatitis, and pancreatitis [12]. Furthermore, high levels of carbohydrates contained in energy drinks can affect fluid absorption and cause gastrointestinal distress [13]. Another mechanism implicated for these changes is the oxidative damage as occurs in the liver and brain [14].

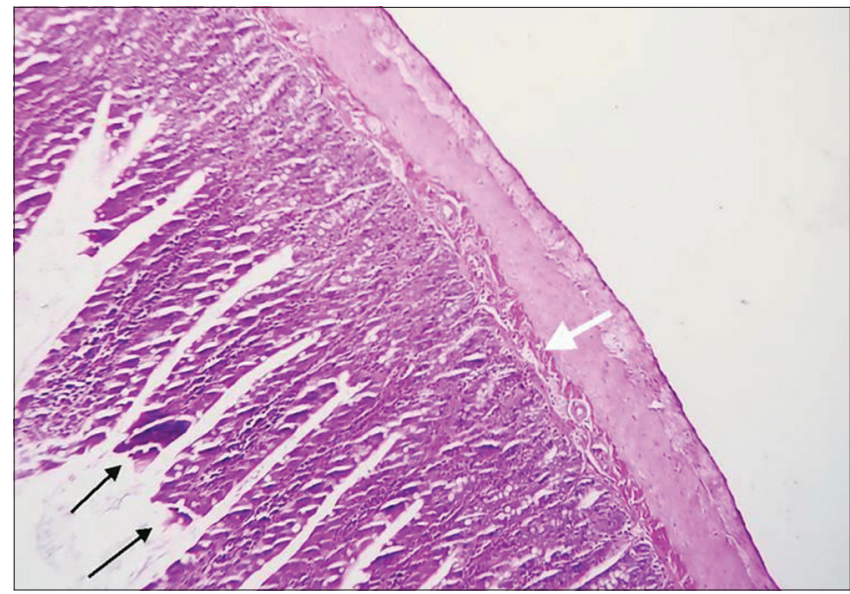

Figure 10: Microscopical picture of intestine tissue of Group B showing congestion of intestinal blood vessels accompanied with a complete layer of hyalinization (white arrow), with partial loss of intestinal villi (black arrows) (hematoxylin and eosin $\times 100$ )

Group C which was given a high dose of energy drink (Tiger) has shown degenerative changes of surface epithelium and infiltration of mononuclear cells which may be an indication for inflammatory process due to the oxidative stress and tissue injury that result from chronic use of energy drink [15]. Goblet cell metaplasia encountered in this group may be a marker for an early progression to gastric cancer [16]. This finding goes with finding of Garg et al. who described

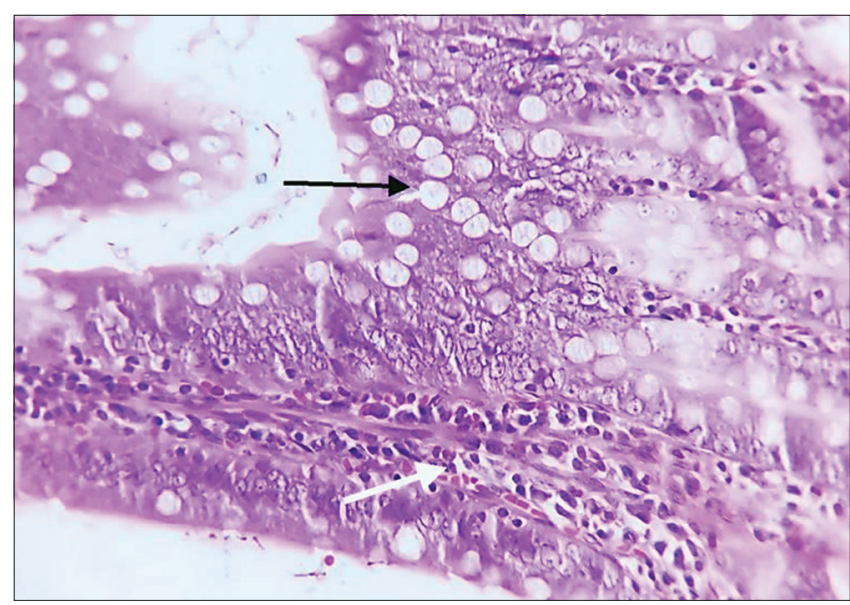

Figure 11: Microscopical picture of intestine tissue of group B showing goblet cell hyperplasia (black arrow) with mild degree of inflammatory mononuclear cells infiltration (white arrow) (hematoxylin and eosin $\times$ 400) 


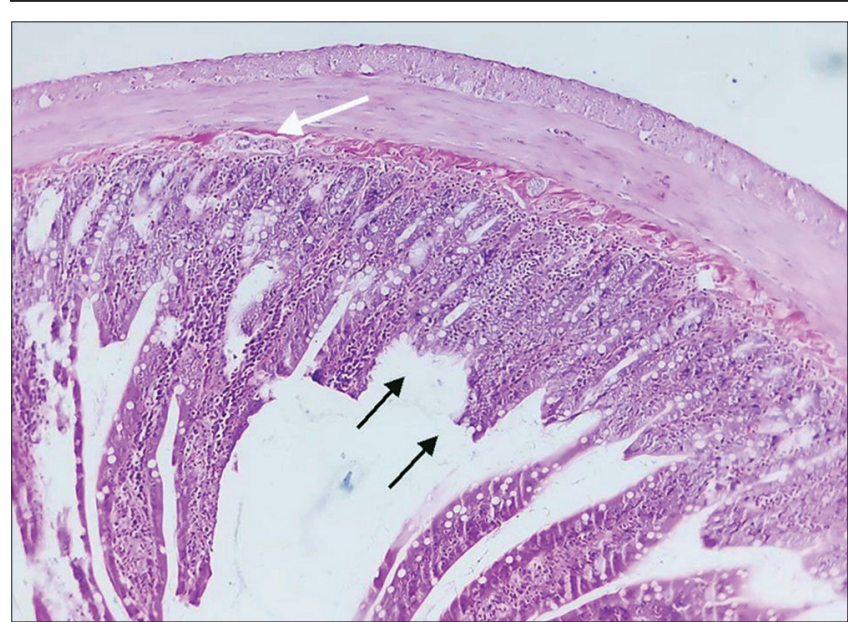

Figure 12: Microscopical picture of intestine tissue of group $C$ showing a complete layer of hyalinization associated with congestion of intestinal blood vessels (white arrow). Furthermore, destruction and complete loss of intestinal villi (black arrows) was seen in this group (hematoxylin and eosin $\times 100$ )

the presence of atrophic gastritis and gastrointestinal metaplasia in relation to increase the dose of energy drinks [17].

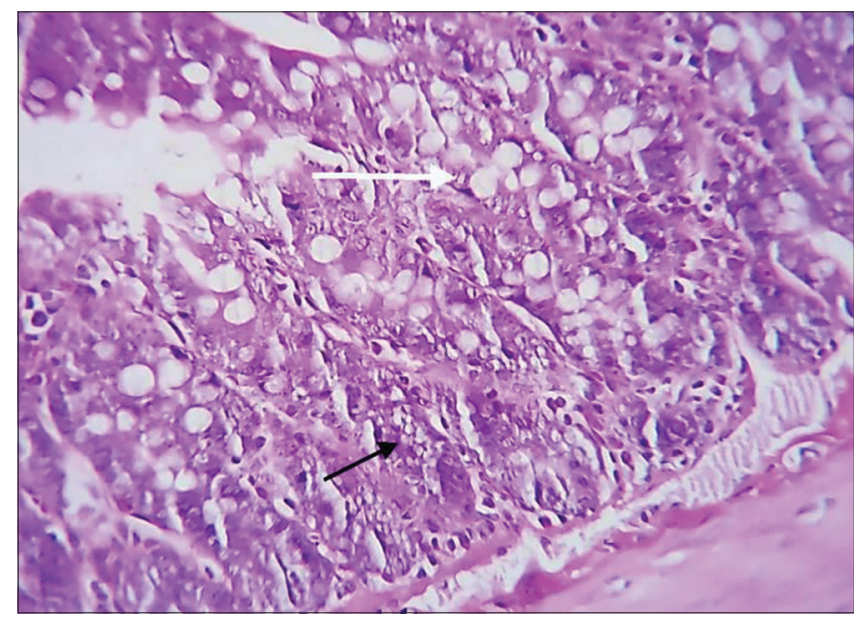

Figure 13: Microscopical picture of intestine tissue of group C showing degeneration of epithelial cells (black arrow) and marked goblet cell hyperplasia (white arrow) (hematoxylin and eosin $\times 400$ )

Regarding intestinal sections, normal histological pattern was found in control group. Group B specimens revealed intestinal blood vessels congestion associated with complete layer of hyalinization, with partial loss of intestinal villi. The reason beyond that may be due to the presence of caffeine which induces elevation of tumor necrosis factor-alpha which leads to nitric oxide synthesis that causes oxidant-antioxidant imbalance which may be the reason for increasing oxidative stress and subsequent cell damage [7]. The lack of tissue oxidative enzymes evaluation was the limitation in the present work since our study was a histological Study rather than biochemical one. Another mechanism attributed for loss of intestinal villi is the additive effect of taurine to the caffeine on intestinal mucosa that results in the conjugation of taurine with bile acid leading to the digestion of lipid including the lipid present in the cell membrane and this leads to marked cellular degeneration and apoptosis [18]. This is inconsistent with the finding of Manzini et al. who found that energy drink consumption may exert an unexpected anti-inflammatory effect on intestinal epithelium [19]. As a cause for congestion of intestinal blood vessels is the effect of energy drink on increasing platelet activity via arachidonic acid-induced platelet aggregation [20].

In sections of group $\mathrm{C}$, marked loss of intestinal villi with evident degeneration of the intestinal epithelium was noted in association with mononuclear cell infiltration and goblet cell hyperplasia. The presence of goblet cell hyperplasia in the intestine and goblet cell metaplasia in the stomach may be explained as continuous consumption of energy drinks can lead to continuous intestinal and gastric injury and irritation which may stimulate the conversion of the normal cells to more resistant type of cells especially in the presence of a large amount of the fluid so the goblet cell will be present in large number to accommodate the large amount of the fluid and this may also predispose to intestinal and gastric carcinoma, this mechanism was not mentioned by other researchers due to the lack of sufficient researches in this field. A recent research had explained the modulation in immunity as an explained mechanism for carcinogenesis due to caffeine contained within the energy drinks [21].

\section{Conclusion}

Consumption of energy drinks for a long period and in large amount has its impact on rat's stomach and intestine in a dose-dependent manner. The most terrifying change encountered is the occurrence of goblet cell metaplasia which could be an early sign of the development of gastric cancer. Further researches are needed to highlight the exact mechanism for these effects and to determine the measures which can be undertaken to prevent them.

\section{Acknowledgments}

The authors would like to express their deepest appreciation to the College of Medicine, University of Mosul for supporting this work. Our thanks to the College of Veterinary Medicine, University of Mosul for their help to accomplish this study. We are grateful to Assistant Professor Dr. Nadwa, Department of Pathology, College of Medicine, Unversity of Mosul for her valuable help. 


\section{References}

1. Kassab AA, Tawfik SM. Effect of a caffeinated energy drink and its withdrawal on the submandibular salivary gland of adult male albino rats: A histological and immunochemical study. EJH. 2018;41:11-26. https://doi.org/10.21608/ejh.2018.7518

2. Ishak WW, Ugochukwu C, Bagot K, Khalil D, Zaky C. Energy drinks: Psychological effects and impact on well-being and quality of life-a literature review. Innov Clin Neurosci. 2012;9(1):25-34.

PMid:22347688

3. Higgens JP, Tuttle TD, Higgens CL. Energy beverages: Content and safety. Mayo Clin Proc. 2010;85(11):1033-41.

PMid:21037046

4. Kopacz A, Wawrzyniak A, Hamułka J, Górnicka M. Evaluation of energy drink intake in selected student groups. Rocz Panstw Zakl Hig. 2013;64(1):49-53.

PMid:23789313

5. Kaminer Y. Problematic use of energy drinks by adolescents. Child Adolesc Psychiatr Clin N Am. 2010;19(3):643-50. PMid:20682226

6. Salih NA, Abdul-Sadaand IH, Abdulrahman NR Histopathological effect of energy drink (red bull) on brain, liver, kidney and heart in rabbits. Med J Babylon. 2018;15(1):16-20. https://doi.org/10.4103/mjbl.mjbl_5_18

7. Costa-Valle MT, Tonieto BD, Altknecht L, Cunha CD, Fão N, Cestonaro LV, et al. Energy drink and alcohol combination leads to kidney and liver alterations in rats. Toxicol Appl Pharmacol. 2018;355:138-46. https://doi.org/10.1016/j.taap.2018.06.024 PMid:29959998

8. Ayuob N, ElBeshbeishy R. Impact of an energy drink on the structure of stomach and pancreas of albino rat: Can omega-3 provide a protection? PLoS One. 2016;11(2):e0149191. https:// doi.org/10.1371/journal.pone.0149191

PMid:26894845

9. Malinauskas BM, Aeby VG, Overton RF, Carpenter-Aeby T, Barber-Heidal K. A survey of energy drink consumption patterns among college students. Nutr J. 2007;6:1-7. https://doi. org/10.1186/1475-2891-6-35

PMid:17974021

10. Tek M, Toptas O, Akkas I, Kazancioglu HO, Firat T, Ezirganli S, et al. Effects of energy drinks on soft tissue healing. J Craniofac Surg. 2014;25:2084-88. https://doi.org/10.1097/ scs.0000000000001013

11. Boekema PJ, Samson $M$, van Berge Henegouwen GP, Smout AJ. Coffee and gastrointestinal function: Facts and fiction. A review. Scand J Gastroenterol Suppl. 1999;34:35-9.

12. Uwaifo GI. Beware Energy drinks: A case of a toxic triad syndrome in diabetic patient with nonalcoholic fatty liver disease. Am J Med Sci. 2019;358(4):304-11. https://doi.org/10.1016/j. amjms.2019.07.015

PMid:31543103

13. Al Yacoub R, Luczkiewicz D, Ken C. Acute kidney injury and hepatitis associated with energy drink consumption: A case report. J Med Case Rep. 2020;14:23-6. https://doi.org/10.1186/ s13256-019-2340-0

14. Reis R, Charehsaz M, Sipahi H, Ekici Al, Macit C, Akkaya H, et al. Energy drink induced lipid peroxidation and oxidative damage in rat liver and brain when used alone or combined with alcohol. J Food Sci. 2017;82(4):1037-43. https://doi. org/10.1111/1750-3841.13662 PMid:28304088

15. Al-Basher GI, Aljabal H, Almeer RS, Allam AA, Mahmoud AM Perinatal exposure to energy drink induces oxidative damage in the liver, kidney and brain, and behavioral alterations in mice offspring. Biomed Pharmacother. 2018;102:798-811. https://doi. org/10.1016/j.biopha.2018.03.139 PMid:29605768

16. Odze R. Histology of Barrett's metaplasia: Do goblet cells matter? Dig Dis Sci. 2018;63(8):2042-51. https://doi. org/10.1007/s10620-018-5151-z PMid:29998421

17. Garg A, Rodriguez A, Lewis JT, Bansal R, Brahmbhatt B. Energy drinks: A reversible risk factor for atrophic gastritis and gastric intestinal metaplasia. Cureus. 2020;12(12):e12298. https://doi. org/10.7759/cureus.12298

PMid:33520500

18. Mohamed RA, Ahmed AM, Al-Matrafi TA, AlRoalle $\mathrm{AH}$ Alfayez MA, Al-Okaiel DM, et al. Energy drinks induce adverse histopathological changes in gastric and duodenal mucosa of rats. IJAAS. 2018;5:81-9. https://doi.org/10.21833/ ijaas.2018.02.014

19. Manzini $R$, Schwarzfischer $M$, Bircher $A$, Niechcial $A$ Vavricka SR, Atrott $\mathrm{K}$, et al. Energy drink administration ameliorates intestinal epithelial barrier defects and reduces acute DSS colitis. Inflamm Bowel Dis. 2021;27(7):1139-52. https://doi.org/10.1093/ibd/izaa328

PMid:33501991

20. Pommerening MJ, Cardenas JC, Radwan ZA, Wade CE, Holcomb JB, Cotton BA. Hypercoagulability after energy drink consumption. J Surg Res. 2015;199(2):635-40. https://doi. org/10.1016/j.jss.2015.06.027 PMid:26188956

21. Cui WQ, Wang ST, Pan D, Chang B, Sang LX. Caffeine and its main targets of colorectal cancer. World J Gastrointest Oncol. 2020;12(2):149-72. https://doi.org/10.4251/wjgo.v12.i2.149 PMid:32104547 